\title{
EVALUATION OF CALCIUM HOMEOSTASIS IN PATIENTS TREATED IN TERNOPIL UNIVERSITY HOSPITAL FOR CHRONIC OBSTRUCTIVE PULMONARY DISEASE
}

\section{OCENA HOMEOSTAZY WAPNIOWEJ U PACJENTÓW LECZONYCH NA PRZEWLEKEA OBTURACYJNĄ CHOROBĘ PŁUC W UNIWERSYTECKIM SZPITALU W TARNOPOLU}

\author{
Oleksandr Oliynyk ${ }^{1(\mathrm{~A}, \mathrm{~B}, \mathrm{C}, \mathrm{D}, \mathrm{E})}$, Maksym Doroshenko ${ }^{1(\mathrm{E})}$, Anna Ślifirczyk $^{2(\mathrm{E}, \mathrm{F})}$
}

${ }^{1}$ I. Horbachevsky Ternopil State Medical University, Ukraine

${ }^{2}$ Pope John Paul II State School of Higher Education in Biała Podlaska, Poland

Authors' contribution Wkład autorów:

A. Study design/planning zaplanowanie badań B. Data collection/entry zebranie danych C. Data analysis/statistics dane - analiza i statystyki D. Data interpretation interpretacja danych E. Preparation of manuscript przygotowanie artykułu F. Literature analysis/search wyszukiwanie i analiza literatury G. Funds collection zebranie funduszy

\section{Summary}

Background. Osteoporosis is a significant problem in patients with advanced Chronic obstructive pulmonary disease. The etiology for the bone loss includes smoking, vitamin D deficiency,concomitant endocrine diseases, sedentary lifestyle, use of glucocorticoids. Osteoporosis is the pathology of calcium metabolism, thus the peculiarities of calcium homeostasis in Chronic obstructive pulmonary disease patients, depending on their bone mineral density were researched in the article.

Material and methods. It was examined 86 patients with stage 3 Chronic obstructive pulmonary disease. Bone densitometry was performed on lumbar vertebrae using dual energy X-ray absorption scanner "Lunar".

Results. It was not find a significant difference in the duration of disease among patients suffering from 3rd stage COPD with or without bone mass deficiency. All females with low bone mineral density had concomitant endocrine pathologies. It was established the increase of calcium content in sputum of patients with COPD. Osteoporosis in patients with chronic obstructive pulmonary disease develops under influence of numerous factors, among which are: lack of physical activity, increase in calcium excretion with urine and sputum, low amount of calcium in diet, reduced exposure to sunlight, concomitant endocrine diseases in females and exposure to stressful situations, smoking, vitamin D deficiency.

Conclusions. Osteoporosis in patients with chronic obstructive pulmonary disease develops under influence of numerous factors, among which are: lack of physical activity, increase in calcium excretion with urine and sputum, low amount of calcium in diet, reduced exposure to sunlight, concomitant endocrine diseases in females and exposure to stressful situations.

Keywords: osteoporosis, chronic obstructive pulmonary disease

\section{Streszczenie}

Wprowadzenie. Osteoporoza stanowi istotny problem wśród pacjentów z zaawansowaną postacią przewlekłej obturacyjnej choroby płuc. Do głównych przyczyn utraty masy kostnej należą: palenie wyrobów tytoniowych, niedobór witaminy D, współistniejące zaburzenia hormonalne, siedzacy tryb życia oraz przyjmowanie glikokortykosteroidów. Osteoporoza to zaburzenie metabolizmu wapnia, dlatego też w tym artykule podjęto próbę zbadania cech szczególnych homeostazy wapnia u pacjentów leczonych na przewlekłą obturacyjną chorobę płuc w zależności od ich gęstości mineralnej kości.

Materiał i metody. Badaniem objęto 86 pacjentów w III stadium przewlekłej obturacyjnej choroby płuc. Pomiar gęstości kości przeprowadzono w odcinku lędźwiowym kręgosłupa za pomoca aparatu Lunar.

Wyniki. Nie zauważono znacznej różnicy czasu trwania choroby pomiędzy pacjentami w III stadium przewlekłej obturacyjnej choroby płuc, u których stwierdzono niedobór masy kostnej a tymi, u których owego niedoboru nie stwierdzono. U wszystkich kobiet $\mathrm{z}$ niską gęstością mineralną kości stwierdzono współistniejące zaburzenia hormonalne. Stwierdzono również wzrost zawartości wapnia w plwocinie pacjentów cierpiących na przewlekłą obturacyjną chorobę płuc. Na rozwój osteoporozy u tychże pacjentów wpływ mają liczne czynniki, m.in. brak aktywności fizycznej, wzrost wydalania wapnia z moczem i plwociną, mała zawartość wapnia w diecie, zmniejszona ekspozycja na światło słoneczne, współistniejące zaburzenia hormonalne u kobiet oraz ekspozycja na czynniki stresogenne, palenie wyrobów tytoniowych oraz niedobór witaminy D.

Wnioski. Na rozwój osteoporozy u pacjentów z zaawansowaną postacią przewlekłej obturacyjnej choroby płuc wpływ mają liczne czynniki, m.in. brak aktywności fizycznej, wzrost wydalania wapnia z moczem i plwocina, mała zawartość wapnia w diecie, zmniejszona ekspozycja na światło słoneczne, współistniejące zaburzenia hormonalne u kobiet oraz ekspozycja na czynniki stresogenne.

Słowa kluczowe: osteoporoza, przewlekła obturacyjna choroba płuc
Tables: 2
Figures: 0

References: 13

Submitted: 30.09 .2015

Accepted: 27.10.2016

Oliynyk 0, Doroshenko M, Slifirczyk A. Evaluation of calcium homeostasis in patients treated in Ternopil University Hospital for chronic obstructive pulmonary disease. Health Problems of Civilization. 2016; 10(4): 60-64. doi: 10.5114/hpc.2016.63573.

Address for correspondence / Adres korespondencyjny: Oleksandr Oliynyk, I. Horbachevsky Ternopil State Medical University, Voli Square 1, Ternopil, Ukraine, e-mail: alexanderoliynyk8@gmail.com, phone: +380 352524492

Copyright: (C) 2016 Pope John Paul II State School of Higher Education in Biała Podlaska, Oleksandr Oliynyk, Maksym Doroshenko, Anna Ślifirczyk. This is an Open Access journal, all articles are distributed under the terms of the Creative Commons Attribution-NonCommercial-ShareAlike 4.0 International (CC BY-NC-SA 4.0) License (http://creativecommons.org/licenses/by-nc-sa/4.0/), allowing third parties to copy and redistribute the material in any medium or format and to remix, transform, and build upon the material, provided the original work is properly cited and states its license. 


\section{Introduction}

Chronic obstructive pulmonary disease (COPD) is among the leading causes of death in the world. Unlike most other major disorders, its prevalence and mortality rate continue to increase $[1,2]$. Nowadays, it ranks fourth among chief chronic incapacitating and death causing pathologies globally in adult age group of $>45$ y.o., preceded only by cardiovascular diseases, lung cancer and cerebrovascular conditions [2]. Apart from pulmonary symptoms, extrapulmonary manifestations and significant concomitant pathologies, as well as complications, can aggravate COPD progression [1]. Osteoporosis is often an accompanying condition, as chronic obstructive pulmonary disease can promote its development [3].

Osteoporosis is the most prevalent bone disorder and affects about every second adult over 50 . The significance of the disease is dictated by its incapacitative potential and increased mortality rate of affected individuals [4]. According to European statistics data, during 2010, femoral fractures were diagnosed in 620000 patients: 574000 individuals had fractures of forearm, 250000 - proximal humerus, and 620000 - fractures of the vertebrae, in both men and women of 50 years of age and older, with clinical osteoporosis as the major contributing factor. These injuries made $34.8 \%$ of all bone fractures registered [5, 6]. Pelvic, costal and lower leg fractures were often osteoporotic in origin as well. The direct costof osteoporosis-relatedfractures among Europeans was estimated at 36 billion Euro. In addition to above mentioned impact broncholitic therapy in COPD patients with concomitant osteoporosis proved to be less efficient.

Primarily, osteoporosis is the pathology of calcium metabolism, thus we aimed to research the peculiarities of calcium homeostasis in COPD patients, depending on their bone mineral density.

\section{Material and methods}

We examined 86 patients with stage 3 COPD: 43 male (mean age - 45.4 years) and 43 female (mean age -38.2 years). All participating female patients had intact reproductive function. Bone densitometry was performed on lumbar vertebrae using dual energy X-ray absorption scanner "Lunar".

T-score was the deciding factor we used in this research to clinically define osteoporosis. T-score is recommended by World Health Organization as the main criterion for diagnosing bone mineral density (BMD) pathologies. The score represents a deviation of patient's BMD from that of healthy adults over 35 y.o., when bones reach their maximum strength and density.

In a healthy population, the T-score is above -1. Osteopenia is usually diagnosed at the rise of bone metabolism pathology, when BMD does not distinctly affect osseal microarchitectonics $(-1<\mathrm{T}<-2.5)$, and the diagnosis of osteoporosis is made when the T-score is below -2.5 .

Spirometry data of all patients was obtained using "Spirosoft" spirometer. Viscosity of sputum was measured with viscosimeter ВПЖ-2. Calcium content in blood, urine and sputum was quantified using colorimetry [7]. The volume of urine and sputum produced during one week was calculated and the above mentioned parameters of calcium metabolism were measured and averaged.

All patients were questioned using special tables for estimation of daily calcium intake $[8,9,10]$ and daily energy expenditure.

\section{Results and discussion}

Patients suffering from osteoporosis tend to have a decrease in height of the spine (spine length deficit) on average of $3.9 \mathrm{~cm}$ (measured by calculating a difference of length between tips of middle fingers on laterally stretched arms and total body height).

Among the study participants with chronic obstructive pulmonary disease, mineral bone mass deficiency was diagnosed in 58 patients or 67\% (table 1). Osteoporosis was diagnosed in 22 patients (25\%): 11 male (26\%) and 10 female (21.7\%) subjects. Osteopenia was found in 37 (43\%) patients: $22(51.16 \%)$ male and $15(34.88 \%)$ female. Osteosclerosis was diagnosed in 14 patients (16.2 \%): 7 male (16.28\%) and 6 female (13.95\%) study participants.

We did not find a significant difference in the duration of disease among patients suffering from 3rd stage COPD with or without bone mass deficiency. Interestingly, all 33 male participants with diagnosed BMD deficiency reported occupational health hazard in anamnesis (most of above mentioned patients worked as welders or smelters for $10-17 \mathrm{y}$.

The anamnesis of participants with normal BMD was unremarkable for occupational hazards. Nevertheless, all females with low BMD had concomitant endocrine pathologies: 9 patients - hyperthyreosis, 5 - thyroiditis, 5 - hypothalamic syndrome, 6 - endometriosis. Only 1 patient of this group was a cigarette smoker. 
Table 1. Characteristic anamnesis features of patients with COPD, in relation to the state of bone mineral density

\begin{tabular}{|c|c|c|c|c|}
\cline { 2 - 5 } \multicolumn{1}{c|}{} & \multicolumn{2}{|c|}{ Male } & \multicolumn{2}{c|}{ Female } \\
\cline { 2 - 5 } \multicolumn{1}{c|}{ Number of examined patients } & $10(23 \% \%)$ & $33(77 \%)^{*}$ & $18(42 \%)$ & $25(58 \%)^{*}$ \\
\hline Mean age, years & $37.5 \pm 4.1$ & $43.6 \pm 3.7$ & $40.3 \pm 3.1$ & $36.6 \pm 3.9$ \\
\hline Average duration of disease, years & $15.1 \pm 2.4$ & $17.6 \pm 1.7$ & $11.0 \pm 2.1$ & $11.2 \pm 2.3$ \\
\hline $\begin{array}{c}\text { Daily energy expenditure, Cal } \\
\text { consumed with daily meals, mg }\end{array}$ & $3031.6 \pm 209.3$ & $2927.4 \pm 197.4$ & $3034.5 \pm 191.4$ & $2852.0 \pm 203.5$ \\
\hline $\begin{array}{c}\text { Number of patients with occupa- } \\
\text { tional health hazard }\end{array}$ & $080.5 \pm 94.0$ & $591.2 \pm 64.3 *$ & $871.3 \pm 71.2$ & $467.0 \pm 44.3^{*}$ \\
\hline $\begin{array}{c}\text { Number of smokers } \\
\text { Nutients }\end{array}$ & $3(7 \%)$ & $33(77 \%)^{*}$ & $0(0 \%)$ & $25(58 \%)^{*}$ \\
\hline $\begin{array}{c}\text { Patienth concomitant endo- } \\
\text { crine diseases }\end{array}$ & $0(0 \%)$ & $33(100 \%)^{*}$ & $0(0 \%)$ & $7(16.28 \%)^{*}$ \\
\hline \begin{tabular}{c} 
T-score \\
\hline$y y y y$
\end{tabular} & $0.20 \pm 0.01$ & $-1.16 \pm-0.10^{*}$ & $0.50 \pm 0.02$ & $25(100 \%)^{*}$ \\
\hline
\end{tabular}

* $\mathrm{P}<0.001$ comparing to respective group with normal BMD.

Among men with $3^{\text {rd }}$ stage COPD and bone mass deficiency - all 33 patients (100\%) were smoking. Only 3 males with normal BMD (7.1\%) had this habit. As for females, 7 patients with low BMD (19\%) smoked, and none did in the group, characterized by normal bone mass.

Also, anamnesis of participants with osteoporosis revealed that most of them had experienced severe stress in the past 2 years.

Analysis of daily energy expenditure showed that patients with COPD and low BMD spent significantly less energy per day than patients with normal BMD. We found 3 cases with longer COPD duration and average for the group external respiratory function, hemodynamic of pulmonary circulation and immunity, where bone mineral density values were normal or even above average. At the same time, we observed patients with relatively short COPD duration, but pronounced osteoporosis. These two groups were significantly different in the level of physical activity and the amount of calcium consumed with food daily. All patients from the above described first group were more physically active, had a longer daily exposure to direct sunlight and consumed more calcium with food.

Conservation of bone mass requires physical activity, decrease in which was proven to promote deficiency of BMD. Many patients, who suffer from COPD with advanced respiratory insufficiency spend much time on stationary hospital treatment and pursue sedentary lifestyle. They experience decreased tolerance to physical exercises for many reasons, including shortness of breath, muscle weakness, etc. [11]. Shortness of breath is the main activity limiting, life quality reducing factor in COPD patients. If the disease is not controlled efficiently, particularly that in stages 3 or 4, patients get locked in a vicious circle, when low physical activity, due to respiratory insufficiency, is accelerating osteoporosis progression. Apart of inducing bone remodeling, exercising stimulates growth hormone release, that is turn increases BMD. As confirmed by previous research, 10 minutes of high intensity physical activity causes a robust increase of growth hormone in young males [12].

Thus, given identical nutrient intake, calcium stores are larger in people leading active lifestyle, then those pursuing the sedentary one.

In our research, we found that dietary calcium intake was significantly different among patients with COPD, who suffered from osteoporosis and those who didn't, including the healthy controls (table 2). The recommended daily amount of calcium consumption for adults younger than 65 years is $1000 \mathrm{mg}$ per day, for those older - 1500 mg. Patients with osteoporosis consumed on average 1.62 times less calcium, then people with normal BMD. Nevertheless, according to our data, no significant difference in plasma concentration of calcium was observed between patients and healthy controls, with different mineral dietary intake. 
Table 2. Comparison of calcium metabolism in patients suffering from chronic obstructive pulmonary disease with or without bone mineral density deficiency

\begin{tabular}{|c|c|c|c|}
\hline & \multirow{2}{*}{ Healthy controls } & \multicolumn{2}{|c|}{ Patients with COPD } \\
\hline & & with osteoporosis & without osteoporosis \\
\hline $\begin{array}{l}\text { Concentration of calcium in blood, } \\
\mathrm{mmol} / \mathrm{l}\end{array}$ & $2.25 \pm 0.15$ & $2.23 \pm 0.22$ & $2.20 \pm 0.17$ \\
\hline $\begin{array}{c}\text { Concentration of calcium in urine, } \\
\mathrm{mmol} / \mathrm{l}\end{array}$ & $2.45 \pm 0.21$ & $2.50 \pm 0.20$ & $1.81 \pm 0.22^{*}$ \\
\hline $\begin{array}{c}\text { Concentration of calcium in sputum, } \\
\mathrm{mmol} / \mathrm{l}\end{array}$ & $9.0 \pm 0.8$ & $12.02 \pm 1.1^{*}$ & $14.35 \pm 1.1^{*}$ \\
\hline $\begin{array}{l}\text { Daily excretion of calcium with urine, } \\
\text { mg/day }\end{array}$ & $166.6 \pm 14.5$ & $170.0 \pm 15.4$ & $157.1 \pm 11.6$ \\
\hline $\begin{array}{l}\text { Daily excretion of calcium with sputum, } \\
\text { mg/day }\end{array}$ & $2.1 \pm 1.0$ & $33.3 \pm 3.1^{*}$ & $67.5 \pm 4.2 * * *$ \\
\hline $\begin{array}{c}\text { Daily dietary intake of calcium, } \\
\text { mg }\end{array}$ & $800.0 \pm 100.0$ & $880.5 \pm 94.0$ & $520.0 \pm 44.3^{* * *}$ \\
\hline
\end{tabular}

$* \mathrm{P}<0.001$ comparing to healthy control group.

** $\mathrm{P}<0.001$ comparing to respective COPD patient group with normal BMD.

Concentration of calcium in sputum of COPD patients with or without osteoporosis was higher than in healthy controls. In urine, the amount of calcium was significantly lower in the group with diagnosed osteoporosis. Taking into account the mean volume of urine produced daily and the amount of calcium excreted with it, we calculated that patients of this group excreted 1.3 times less of this element, than controls or those from COPD without concomitant osteoporosis group.

The increase in calcium excretion can be achieved by excess intake of sodium chloride or large quantity of proteins. Still, consumption of proteins in recommended daily amounts does not usually affect calcium excretion [13]. We also didn't find that people with hypercalciuria consumed more salt or proteins.It was concluded that patients with COPD and concomitant osteoporosis had twice more calcium excreted with sputum than patients with COPD and normal bone mass. An average concentration of calcium in sputum of participants was 11.1 $\mathrm{mmol} / \mathrm{l}$, that is approximately 4.9 times higher than average level of calcium in serum (table 2).

Taking into account the relatively low amount of sputum excreted, the daily calcium loss with expectorated matter makes about $20-25 \%$ of net daily calcium excretions. Still, patients who produce a lot of sputum may lose more calcium with it than excreted in urine. It is known that destruction of alveoli in an experimental emphysema leads to reduction of capillary bed, which may be the cause of elevated calcium level in sputum [13].

After summing up the amounts of calcium excreted with urine and sputum, we found that net calcium loss of COPD patients with osteoporosis is 2.1 times higher than that of patients without osteoporosis.

The fact that chronic obstructive pulmonary disease is a major contributing factor of osteoporosis development is not new. The results of our research, supports previous works that investigate causes of augmented osteoporosis development in patients with COPD. Among them are lack of physical activity, concomitant endocrine diseases in females, stressful situations in anamnesis, reduced exposure to sunlight and decreased amount of calcium in diet. Nonetheless, we did not find any paper that would evaluate the calcium content in sputum and calculate the calcium loss with expectorated matter. It is known that concentration of calcium is the highest in cartilage. Thus, it is possible that the increase of calcium content in sputum of patients with COPD is the result of destructive processes in scaffolding cartilage of small bronchi, as the emphysema continues to form. Considering that the volume of expectorated masses, produced by patients with COPD, can be quite large, the factor of calcium loss with sputum has to be accounted for.

\section{Conclusion}

Osteoporosis in patients with chronic obstructive pulmonary disease develops under influence of numerous factors, among which are: lack of physical activity, increase in calcium excretion with urine and sputum, low amount of calcium in diet, reduced exposure to sunlight, concomitant endocrine diseases in females and exposure to stressful situations. 


\section{References:}

1. GOLD Report, Global Strategy for COPD Diagnosis, Management, and Prevention (Changes Marked) [cited 2016 Jun 07]. Available from: www.goldcopd.org/.../guidelines-global-strateg.

2. Mannino DM. Does Undiagnosed Chronic Obstructive Pulmonary Disease Matter? Am J Respir Crit Care Med. 2016; 194(3): 250-2.

3. Dvoretskij LI. Chronic obstructive pulmonary disease and osteoporosis. Russian Medical Journal. 2012; 6: 422-429 (in Russian).

4. Briot K, Cortet B, Roux C, Fardet L, 2014 update of recommendations on the prevention and treatment of glucocorticoid-induced osteoporosis. Joint Bone Spine. 2014; 81(6): 493-501.

5. Emkey G, Epstein S. Secondary osteoporosis: Pathophysiology \&amp; diagnosis. Best Pract. Res. Clin. Endocrinol. Metab. 2014; 28(6): 911-935.

6. Soriano R, Herrera S, Nogués X. Current and future treatments of secondary osteoporosis. Best Pract. Res. Clin. Endocrinol. Metab. 2014; 28(6): 885-894.

7. Kamyshnikov VS. Handbook of clinical and biochemical studies and laboratory diagnosis. Publishing house MED.press-informelarus;2009 (in Russian).

8. Calorie and chemical composition of products United States Department of Agriculture, USDA National Nutrient Database for Standard Reference Release [cited 2016 Jun 27]. Available from: http://www.health-diet. ru/table_calorie.

9. The calcium content of foods legscorrection [cited 2016 Jun 23]. Available from: http://www. ru/plastic/ health_1.php.

10. Katz Y. Sports physiology: a textbook for physical education. Moscow: Publishing house: Physical Culture and Sports; 2008 (in Russian).

11. Lin LP, Hsu SW, Yao CH. Risk for osteopenia and osteoporosis in institution-dwelling individuals with intellectual and/or developmental disabilities. Res. Dev. Disabil. 2014; 36C: 108-113.

12. Bor A, Matuz M, Gyimesi N. Gender inequalities in the treatment of osteoporosis. Maturitas. 2014; 11: S03780398.

13. Galindo Zavala R, Núñez Cuadros E, Díaz Cordovés-Rego G. Advances in the treatment of secondary osteoporosis. An Pediatr (Barc). 2014; 22: 287-292. 